\title{
Paleoclimatic reconstruction to the Eocene/Oligocene in the Fonseca district, Minas Gerais, Brazil.
}

\author{
Daniele Zangrossi (IC), Francisco Santiago (PG), Fresia Ricardi-Branco (PQ).
}

\begin{abstract}
Based on leaf physiognomy of the Fonseca Formation paleoflora (Eocene/Oligocene), outcropping in the district of Fonseca, Minas Gerais, a quantitative paleoclimate reconstruction was performed using the Leaf Margin Analysis and the Leaf Area Analysis. The results of these analyses, based on 20 identified morphotypes, indicate that the paleoflora of Fonseca dwells in an environment with a mean annual temperature (MAT) between 27 and $27.7^{\circ} \mathrm{C}$, and a mean annual precipitation (MAP) between 1004 and $1135 \mathrm{~mm}$. The analysis of the obtained values and taxonomic data suggests the presence of a warm and sub-humid tropical climate.
\end{abstract}

Key words: Leaf physiognomy, Fonseca Formation, Sub-humid tropical climate.

\section{Introduction}

The analysis of the relation between the leaf physiognomy of woody dicotyledonous angiosperms and the climate allowed the development of methods for reconstructing the paleoclimate on the basis of fossil leaves ${ }^{1,2}$.

In the district of Fonseca $\left(20^{\circ} 09^{\prime} 21^{\prime \prime S}\right.$ $43^{\circ} 18^{\prime} 44^{\prime \prime W}$ ), Minas Gerais, Brazil, deposits crop out on the Fonseca Formation, which contains an important fossiliferous record of insects, fish and vegetables ${ }^{3}$.

The objective of this project is the reconstruction of the climate of the district of Fonseca during the Eocene/Oligocene (38-28 Ma.), based on fossil leaves of the Fonseca Formation.

\section{Results and Discussion}

We analyzed a total of 26 angiosperm fossil samples. These were described according to the Manual of Leaf Architecture ${ }^{4}$, allowing their later classification into 20 morphotypes.

The estimate of the MAT was performed using equations based on the Leaf Margin Analysis ${ }^{1,5}$, which relates the percentage of woody dicotyledonous species with no teeth of a flora to the MAT ${ }^{1}$. Thus we obtained temperature values between 27 and $27.7^{\circ} \mathrm{C}$, which are similar to the value of $26.9{ }^{\circ} \mathrm{C}$ reported previously for this paleoflora ${ }^{6}$.

The estimate of the MAP was performed using equations based on the Leaf Area Analysis ${ }^{2,7}$, which relates the foliar area of the species of flora to the MAP ${ }^{2}$. The obtained values were between 1004 and $1135 \mathrm{~mm}$, which is below the $1200 \mathrm{~mm}$ previously estimated ${ }^{8}$.
The values of MAT and MAP correspond to a warm and sub-humid tropical climate. This climatic condition is different to those previously reported by other authors who make reference to a humid climate, tropical and subtropical ${ }^{6,8}$.

\section{Conclusions}

The results obtained here, analyzed in conjunction with previously published taxonomic data, allow us to infer a warm and sub-humid tropical climate, for the time when the Fonseca Formation was deposited during the Eocene-Oligocene transition in southeastern Brazil.

\section{Acknowledgement}

The authors wish to thank PIBIC/CNPq for granting the Scientific Initiation scholarship to the the first author listed, as well as the IGEO-UFRJ and the Museum of DNPM for providing the material.

\footnotetext{
Wilf, P. Paleobiology 1997, 23, 373-390.

${ }^{2}$ Wilf, P.; Wing, S. L.; Greenwood, D. R. e Greenwood, C. L. Geology 1998, 26, 203-206.

${ }^{3}$ Mello, C. L.; Bergqvist, L.P. e Sant'Anna, L.G. Sítio Paleontológico de Fonseca, Minas Gerais (Vegetais fósseis do Terciário Brasileiro). Em: C. Schobbenhaus, D. A.; Campos, E. T.; Queiroz, M. Winge e M. Berbert-Born (eds.), Sítios geológicos e paleontológicos do Brasil. [http://www.unb.br/ig/sigep/sitio086/sitio086.pdf/]

${ }^{4}$ Ellis, B.; Daly, D. C.; Hickey, L. J.; Johnson, K. R.; Mitchell, J. D.; Wilf, P. e Wing, S.L. Manual of Leaf Architecture. 2009.

${ }^{5}$ Hinojosa, L. F.; Pérez, F.; Gaxiola, A. e Sandoval, I. Global Ecol Biogeogr 2011, 20, 380-390.

${ }^{6}$ Fanton, J. C. M. Reconstruindo as florestas tropicais úmidas do Eoceno-Oligoceno do sudeste do Brasil (Bacias de Fonseca e Gandarela, Minas Gerais) com folhas de Fabaceae, Myrtaceae e outras angiospermas: origens da Mata Atlântica. 2013.

${ }^{7}$ Jacobs, B. F. e Herendeen, P. S. Palaeogeogr. Palaeoclimatol. Palaeoecol. 2004, 213, 115-123.

${ }^{8}$ Burnham, R. J. e Johnson, K. R. Philos T Roy Soc B 2004, 359, $1595-1610$.
} 